\title{
Conodonts from the Ordovician of East Greenland
}

\author{
M. P. Smith \\ Department of Geology, Nottingham University, Nottingham NG7 2RD, U.K.
}

The Cambro-Ordovician of East Greenland outcrops in a narrow belt between Canning Land $\left(71^{\circ} 36^{\prime}\right)$ and C. H. Ostenfeld Nunatak $\left(72^{\circ} 22^{\prime} \mathrm{N}\right)$. The uppermost three units, namely the Cape Weber, Narwhale Sound and Heim Bjerge Formations of the $4000 \mathrm{~m}$ thick sequence, have been sampled for conodonts.

The Cape Weber Formation $(1165 \mathrm{~m})$ consists of an extremely uniform sequence of massive limestones and dolomitic limestones, often with chert bands. Conodonts have been recovered from throughout the formation and those from the top $150 \mathrm{~m}$ have a typical Late Canadian (late Early Ordovician) aspect. Long ranging species such as Glyptoconus quadraplicatus (Branson \& Mehl), Eucharodus parallelus (Branson \& Mehl) and 'Scolopodus' gracilis Ethington \& Clark are found together with Oepikodus communis (Ethington \& Clark), Microzarkodina? marathonensis (Bradshaw), Protopanderodus? asymmetricus Barnes \& Poplawski, 'Scolopodus' paracornuformis Ethington \& Clark and Bergstroemognathus extensus (Graves \& Ellison).

The Narwhale Sound Formation is $462 \mathrm{~m}$ thick, of which the lower 70-110 m are composed of massive, coarsely crystalline dolomite and calcareous dolomite. The remainder of the formation consists of more thinly-bedded dolomitic limestones and limestones. The conodont fauna from the lower part of the formation is exceedingly sparse with only a few elements of ' $S$.' gracilis recovered. The fauna becomes more diverse approximately $150 \mathrm{~m}$ above the base, the principal species present being ' $S$.' gracilis, $P . ?$ asymmetricus and G. quadraplicatus. The first true Whiterock conodont found is Multioistodus auritus (Harris \& Harris) which appears $215 \mathrm{~m}$ above the base of the formation. The Canadian-Whiterock boundary thus occurs within the lower half of the Narwhale Sound Formation.

The upper half of the Narwhale Sound Formation contains typical Whiterock taxa with various species of Multioistodus, Chosonodina rigbyi, Ethington \& Clark and Histiodella holodentata Ethington \& Clark being present. The upper $130 \mathrm{~m}$ of the formation in Albert Bjerge contain the characteristic upper Whiterock species Paraprioniodus costatus (Mound) together with Scandodus? sinuosus (Mound) and New Genus 4 of Ethington \& Clark (1982). These species continue into the Heim Bjerge Formation, which is composed of uniform, massive, well-bedded grey limestones. $P$. costatus and $S$.? sinuosus continue to be present, together with Stereoconus cf. S. circulus Moskalenko, until $120 \mathrm{~m}$ above the base where they are replaced by Erraticodon balticus Dzik, Belodella nevadensis (Ethington \& Schumacher) and species of Panderodus, together with small numbers of 'Acontiodus' nevadensis Ethington \& Schumacher and a new genus and species figured by Harris et al. (1979). This changeover corresponds approximately to the Whiterock-Chazy boundary. Just below the sub-Devonian unconformity in Albert Heim Bjerge, a single haddingodiform element of Pygodus sp. was recovered, indicating a Late Chazy age.

Frykman (1979) noted that the Heim Bjerge Formation on C. H. Ostenfeld Nunatak attains a thickness of $1200 \mathrm{~m}$ before it is truncated by the sub-Devonian unconformity - more than twice the thickness recorded in Albert Heim Bjerge. The upper $100 \mathrm{~m}$ of this sequence were sampled in detail and yielded E. balticus, B. nevadensis, Belodina monitorensis Ethington \& Schumacher, Appalachignathus delicatulus Bergström et al. and Pygodus cf. P. anserinus (Lamont \& Lindström). The presence of $P$. cf. $P$. anserinus approximately $90 \mathrm{~m}$ below the unconformity on C. H. Ostenfeld Nunatak indicates a Chazy age. A sample from immediately below the unconformity contained $B$. nevadensis. The Heim Bjerge Formation contains the youngest Lower Palaeozic sediments in the East Greenland segment of the Caledonides. There is thus no conodont evidence for post-Chazy sediments in the Ordovician of East Greenland.

\section{References}

Ethington, R. L. \& Clark, D. L. 1982: Lower and Middle Ordovician conodonts from the Ibex Area, Western Millard County, Utah. Brigham Young Univ. Geol. Studies 28(2), 155 pp.

Frykman, P. 1979: Cambro-Ordovician rocks of C. H. Ostenfeld Nunatak, northern East Greenland. Rapp. Grenlands geol. Unders. 91, 125-132.

Harris, A. G., Bergström, S. M., Ethington, R. L. \& Ross, R. J. Jr. 1979: Aspects of Middle and Upper Ordovician conodont biostratigraphy of carbonate facies in Nevada and southeast California and comparison with some Appalachian successions. Brigham Young Univ. Geol. Studies 26, 7-44. 